\title{
Application of Scaevola taccada (Gaertn.) Roxb. Reduce Pro-inflammatory Cytokines Interleukin-1 $\beta$ in Sprague Dawley Mice Suffering from Mastitis
}

\author{
Prihantono Prihantono ${ }^{1 *}$, Salman Ardi Syamsu ${ }^{1}$, Nilam Smaradhania $^{1}$, Mardiana Ahmad ${ }^{2}$, Nurul Aini Siagian ${ }^{3}$, Kholilah Lubis ${ }^{4}$, \\ Andi Sitti Umrah ${ }^{5}$ \\ ${ }^{1}$ Department of Surgery, Faculty of Medicine, Universitas Hasanuddin, Makassar, Indonesia; ${ }^{2}$ Midwifery Postgraduate School, \\ Universitas Hasanuddin, Makassar, Indonesia; ${ }^{3}$ Midwifery, Deli Husada Deli Tua Institute, Medan, Indonesia; ${ }^{4}$ Midwifery, Medan \\ Health Polytechnic, Medan, Indonesia; ${ }^{5}$ Muhammadiyah Palopo Midwifery Academy, Palopo District, Indonesia
}

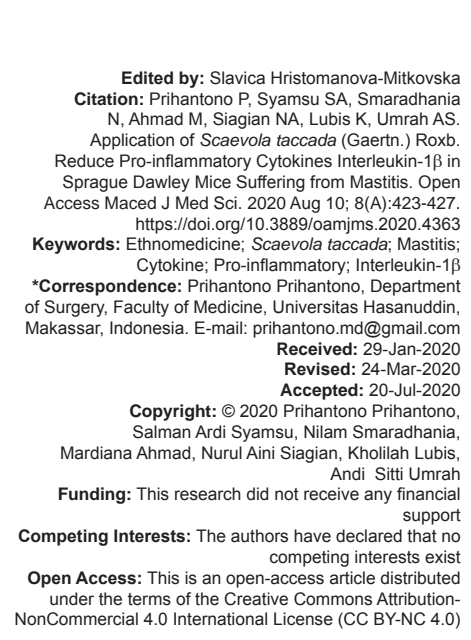

\section{Introduction}

Scaevola taccada (Gaertn. Roxb.) is a dense, spreading shrub that grows in coastal areas, precisely in the waters of tropical regions. This plant is commonly found in Indonesia, including in coastal areas in Makassar Strait. The specific characteristics of this plant include green leaves that contain a lot of water, the flowers are white, and the fruits are green [1], [2], [3].

S. taccada (Gaertn) Roxb. contains chemical compounds such as flavonoid, lipid, terpenoid, alkaloid, and saponin. This plant is commonly used as ethnomedicine in Indonesia, particularly for healing wounds. It is also utilized for healing various diseases that include beriberi, infection of the eye, sore, dysentery, skin disease, coughs and influenza, malaria, tuberculosis, pain due to menstruation, headache, injury, and contraception drugs. In addition, it has significant functions as antitumor, anti-inflammatory, antibacterial, antifungal, antioxidant, and antiviral effects. Local people generally process this plant as the traditional medicine by boiling method, and directly put the concoction of this plant on injured parts of the body in the form of squeezed juices [4], [5], [6], [7].

IL-1 $\beta$ belongs to a member of the IL-1 family that plays significant functions as a pro-inflammatory cytokine, and it has agonist activity. IL-1 $\beta$ is seldom or even unexpressed in healthy cells or tissues. However, this pro-inflammatory cytokine is rapidly expressed in cells or activated by receptors during the invasion of pathogens or damaged cells [8], [9]. 
IL- $1 \beta$ is produced by hematopoietic cells. The secretion of IL-1 $\beta$ is regulated through intracellular and extracellular multiprotein complexes that require caspase- 1 to activate, cleavage, and secrete an active cytokine. When injury or inflammation takes place in various conditions, IL-1 $\beta$ is activated by inducing reaction of inflammation and transmission of pain at different levels; even it causes chronic pain [10], [11].

Mastitis is an inflammation of the breast due to bacteria. This inflammation disease is caused by Staphylococcus aureus that stimulates the secretion of pro-inflammatory cytokine IL-1 $\beta$ that induces inflammation [12], [13].

This study aimed to analyze the profile of IL-1 $\beta$ before and after the administration of leaf extracts of S. taccada (Gaertn) Roxb. to the mastitis model mice of Sprague Dawley strain.

\section{Materials and Methods}

\section{Materials}

Fresh leaves of S. taccada (Gaertn) Roxb. were collected from the local coastal areas in Makassar Strait, located in Subdistrict Suppa, Pinrang District, South Sulawesi Province, Indonesia.

\section{Extraction process}

Fresh leaves of S. taccada (Gaertn) Roxb. were washed well with water, and then they were cut into small pieces. After that, the fresh leaves dried using herbs dryer at $45^{\circ} \mathrm{C}$ for 4 days. Subsequently, the dried leaves of S. taccada (Gaertn). Roxb. were grinded and filtered with the 40 mesh size to gain refined powders, and then they were repeatedly macerated using $70 \%$ ethanol for 3 days. Afterward, the macerated leaves evaporated using a rotary Rotavapor until formed congealed extracts, and then they were weighted with $400 \mathrm{mg} / \mathrm{gr}$ body weight [2], [6].

\section{Phytochemical screening}

The congealed leaf extracts of $S$. taccada (Gaertn) Roxb. were screened using phytochemical screening to identify their bioactive compounds that contained flavonoid, alkaloid, steroid, saponin, and tannin [14], [15].

\section{Bacterial culture}

The bacterial strain used in this study was S. aureus. This bacterial species is a common strain that induces mastitis. Strains of $S$. aureus were derived from the Laboratory of Microbiology at the General Hospital of Hasanuddin University in Makassar, and those bacteria were cultured on Mannitol Salt Agar media based on the standard requirement of $S$. aureus McFarland of $10^{5}-10^{8} \mathrm{ml} / \mathrm{cells}$.

\section{Test method on the experimental animals}

The method used in this study was a true control group experiment using the pre-test-post-test control design. The experimental animals were mice of Sprague Dawley strain. The numbers of treated animals were 18 mice with $200-250 \mathrm{~g}$ body weight. The treated mice were divided into three groups, and each group consisted of six mice. The mice of Group I (negative control) were given $1 \mathrm{ml}$ aquabides/250 g body weight, Group II (positive control) were given $9.6 \mathrm{mg}$ amoxicillin $/ 250 \mathrm{~g}$ body weight, and Group III (treatment) were given $9.6 \mathrm{mg}$ amoxicillin/250 g body weight $+400 \mathrm{mg}$ leaf extracts of $S$. taccada/gr body weight, respectively.

IL-1 $\beta$ levels were measured in three replications for all the treated mice groups. The measurement I was conducted before induction of $S$. aureus. The measurement II was performed in $\pm 24 \mathrm{~h}$ later after induction of $S$. aureus with the dose of $0.1 \mathrm{ml} / 10^{5}-10^{8}$ cells that affected breast tissues of lactiferous ducts in the treated mice. The measurement III was done 5 days later after treatment for each treated group.

Pathological examinations of breast tissues were then conducted for each treated group to prove the healing process. IL-1 $\beta$ levels were determined using the enzyme-linked immunosorbent assay.

\section{Statistical analysis}

Data presented in the form of mean value \pm standard deviation at confidence interval 95\%. ANOVA test was used to determine the statistically significant differences among all the treated mice groups after the measurement of IL-1 $\beta$ levels.

\section{Results}

Results of phytochemical screening were qualitatively done in leaf extracts of $S$. taccada (Gaertn) Roxb. by giving $70 \%$ ethanol, and their extracts contained bioactive compounds that include alkaloid, flavonoid, terpenoid, saponin, and tannin.

As indicated in Table 1, the pro-inflammatory cytokine of IL-1 $\beta$ in all the three treated mice groups for the measurements I, II, and III showed statistically significant differences within the critical limit value of $p<0.05$. Therefore, there were substantial differences 
Table 1: The profile of cytokine pro-inflammatory IL-1 $\beta$ in through the administration of leaf extracts of Scaevola taccada (Gaertn.) Roxb. in mastitis

\begin{tabular}{|c|c|c|c|c|c|}
\hline \multirow[t]{3}{*}{ Group } & \multirow[t]{3}{*}{ Treatment } & \multicolumn{3}{|c|}{ Measurement of IL-1 $\beta$ levels } & \multirow[t]{3}{*}{$\mathrm{p}$-value } \\
\hline & & $\begin{array}{l}\text { I (Before induction } \\
\text { by S. aureus) }\end{array}$ & $\begin{array}{l}\text { II ( } \pm 24 \mathrm{~h} \text { later after } \\
\text { induction by S. aureus) }\end{array}$ & $\begin{array}{l}\text { III (After treatment } \\
\text { for } 5 \text { days) }\end{array}$ & \\
\hline & & Mean \pm SD & Mean \pm SD & Mean \pm SD & \\
\hline Group I (negative control) & $1 \mathrm{ml}$ aquabides $/ 250 \mathrm{~g}$ body weight & $0.53 \pm 0.37$ & $5.79 \pm 0.67$ & $11.02 \pm 2.54$ & $0.00^{\mathrm{a}}$ \\
\hline Group II (positive control) & $9.6 \mathrm{mg}$ amoxicillin $/ 250 \mathrm{~g}$ body weight & $0.54 \pm 0.28$ & $6.54 \pm 1.01$ & $3.82 \pm 0.30$ & $0.00^{\mathrm{a}}$ \\
\hline Group III (Treatment) & $\begin{array}{l}9.6 \mathrm{mg} \text { amoxicillin } / 250 \mathrm{~g} \text { body weight }+400 \mathrm{mg} \text { leaf extracts of } \\
\text { Scaevola taccada (Gaertn) Roxb./kg body weight }\end{array}$ & $0.63 \pm 0.23$ & $6.10 \pm 1.14$ & $1.45 \pm 0.59$ & $0.001^{\mathrm{a}}$ \\
\hline
\end{tabular}

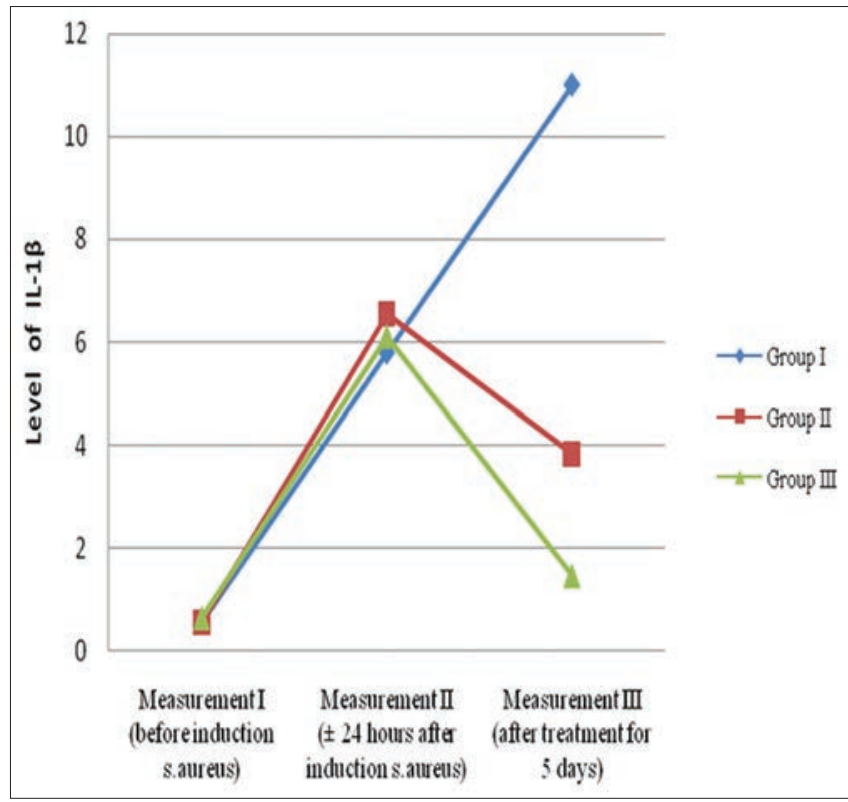

Figure 1: The graph of the cytokine pro-inflammatory IL-1 $\beta$ levels in mastitis through the effect of leaf extracts of Scaevola Taccada (Gaertn.) Roxb

in IL-1 $\beta$ levels in all the treated groups for the measurements I, II, and III.

In the Group I, the IL-1 $\beta$ levels increased for the measurement I until III with the mean value $\pm 10.48 \mathrm{pg} / \mathrm{ml}$ at $\mathrm{p}=0.00$. Therefore, there were statistically significant differences in IL-1 $\beta$ levels during measurement.

In Group II, the IL-1 $\beta$ levels increased for the measurement I until III with the mean value $\pm 6.0 \mathrm{pg} / \mathrm{ml}$. Then, the IL-1 $\beta$ levels reduced after the treatment of $9.6 \mathrm{mg}$ amoxicillin $/ 250 \mathrm{~g}$ body weight with the mean value $\pm 2.72 \mathrm{pg} / \mathrm{ml}$ at $\rho=0.00$. This indicated that there were statistically significant differences in IL-1 $\beta$ levels during measurement.

In Group III, the IL-1 $\beta$ levels increased for the measurement I until III with the mean value \pm $5.47 \mathrm{pg} / \mathrm{ml}$. Then, the IL-1 $\beta$ levels reduced after the treatment of $9.6 \mathrm{mg}$ amoxicillin $/ 250 \mathrm{~g}$ body weight +400 $\mathrm{ml}$ leaf extracts of $S$. taccada (Gaertn.) Roxb. with the mean value $\pm 4.57 \mathrm{pg} / \mathrm{ml}$ at $p=0.01$. This showed that there were statistically significant differences in IL-1 $\beta$ levels during measurement (Figures 1 and 2).

Description of the figures: Figure 1: Microscopic examination of the breast tissues in normal mice. (a) blood vessels, (b) epithelial cells, (3) lactiferous ducts. Figure 2: Microscopic examination of the breast tissues in treated mice for the group I (negative control) in 5 days later after treatment. (a) blood vessels, (b) epithelial cells, (3) lactiferous ducts. (a) Inflamed cells (PMNs or polymorphonuclear leukocytes) were shown around epithelial cells and connective tissues, (b) blood vessels. There were \pm 250 inflamed cells in breast tissues. Figure 3: Microscopic examination of the breast tissues in treated mice for group II (positive control) in 5 days later after treatment. (a) Inflamed cells (PMNs or polymorphonuclear leukocytes) were shown around epithelial cells and connective tissues, but their numbers were reduced at a later time. There were \pm 70 inflamed cells in breast tissues. Figure 4: Microscopic examination of the breast tissues in treated mice for the group III (positive control) in 5 days later after treatment. (a) The inflamed cells (PMNs or polymorphonuclear leukocytes) were shown around lactiferous ducts, (b) the inflamed cells (PMNs or polymorphonuclear leukocytes) were shown around connective tissues and epithelial cells, but their numbers were reduced at a later time. There were \pm 30 inflamed cells in breast tissues.

\section{Discussion and Conclusion}

Induction of $S$. aureus on breast tissues of the treated mice delivered significant evidence to assess the activity of cytokine IL- $\beta$ profile as a pro-inflammatory agent in mastitis conditions.

IL-1 $\beta$ is a pro-inflammatory cytokine, and it is activated by the invasion of pathogens or damaged cells [8], [9]. During inflammation process, cytokine $\mathrm{IL}-1 \beta$ is rapidly increased and induces reaction of inflammation or transmission of pain at various levels, even it persists that causes chronic pain [10], [11].

Exposure of $S$. aureus can regulate the expression of TLR2 in $\mathrm{mRNA}$ and proteins, increases the production of IL-1 $\beta$ dan TNF- $\alpha$, and stimulates the expression of NF-KB [16].

Based on the results of the treatment for all the experimental mice, the Group III (treatment) could rapidly reduce IL-1 $\beta$ levels; even their levels almost achieved IL-1 $\beta$ levels before induction by $S$. aureus. Reduction of these IL-1 $\beta$ levels associated with the functions of bioactive 


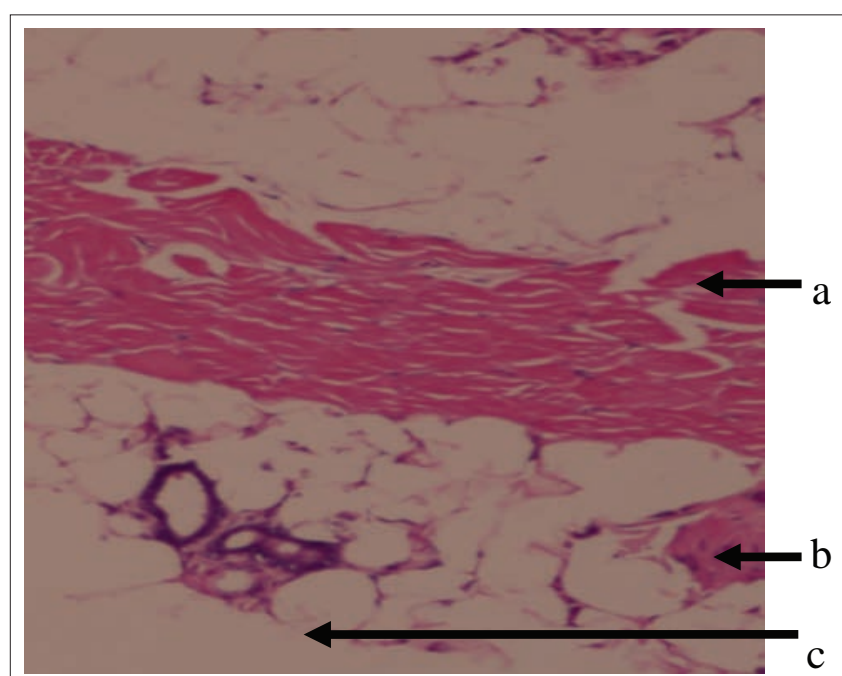

$50 \mu \mathrm{m}$

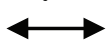

B reast tissues in healthy mice

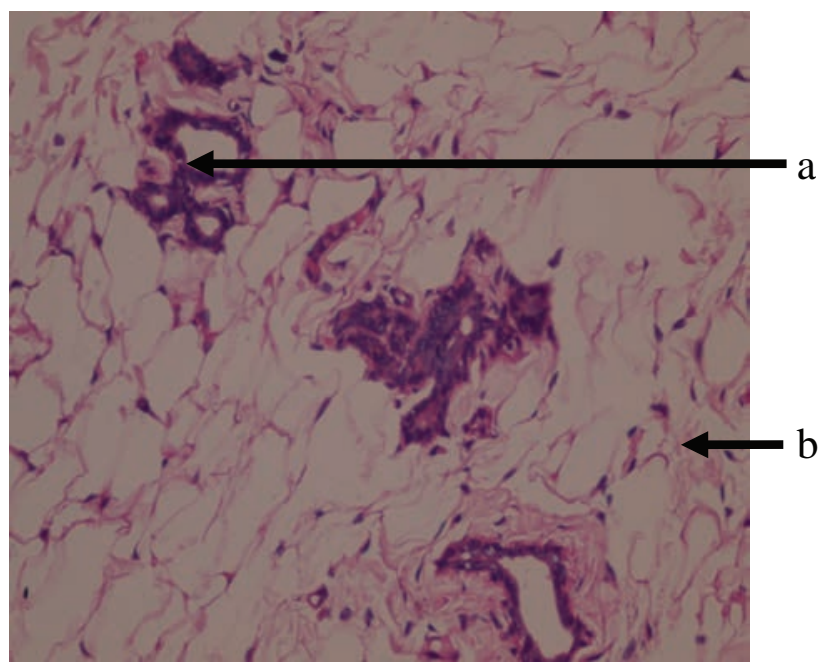

\section{$50 \mu \mathrm{m}$}

(3)

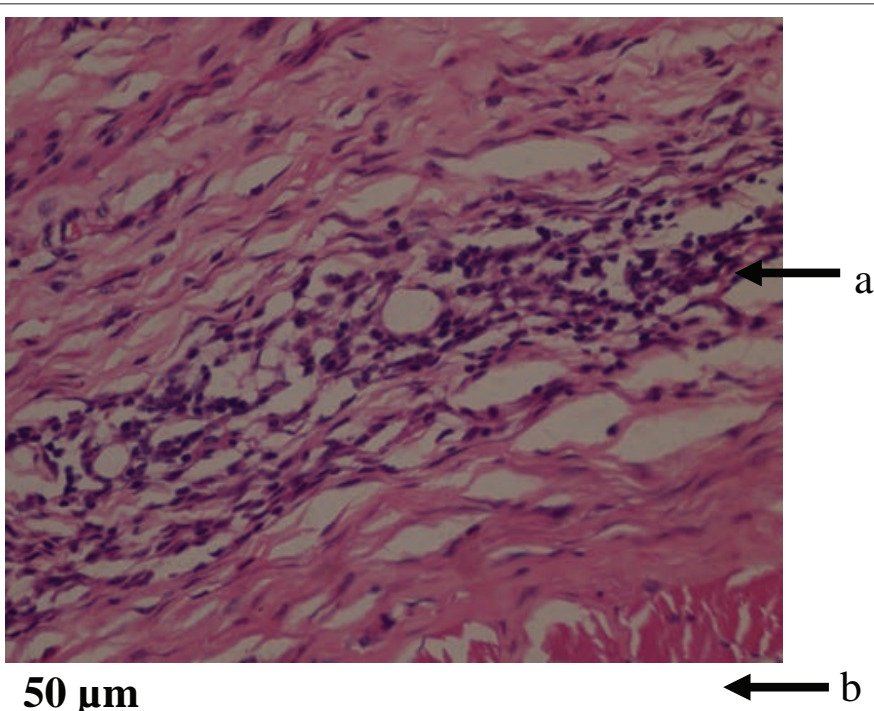

(2)

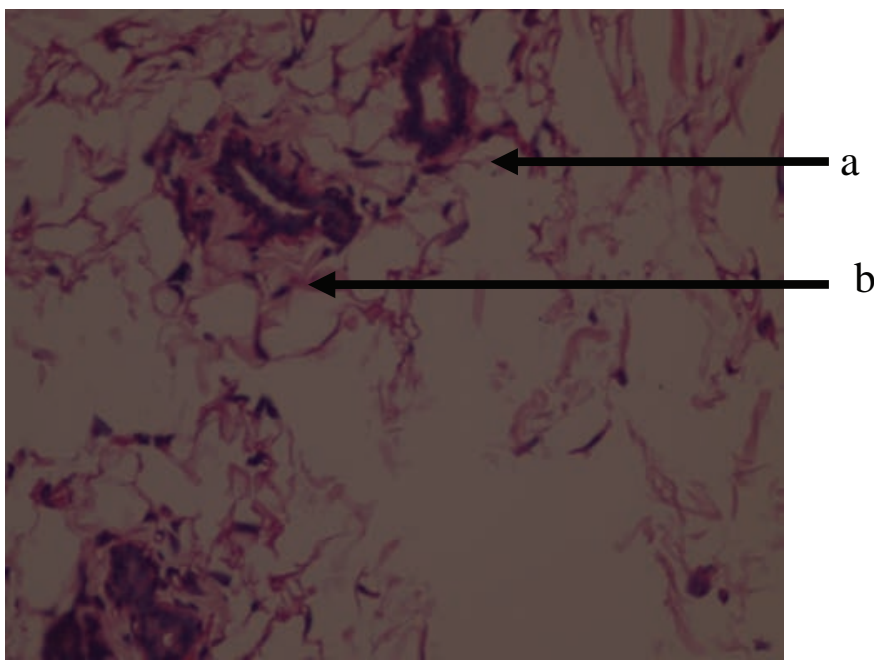

$50 \mu \mathrm{m}$

(4)

B reast tissues in Group III

Figure 2: Results of the histopathological examinations of breast tissues

compounds in leaf extracts of S. taccada (Gaertn.) Roxb. that contain flavonoid, saponin, tannin, terpenoid, and alkaloid that inhibit the activity of COX enzyme and lipooxygenase that reduce biosynthesis of prostaglandins, accumulation of leukocytes, and degranulation of neutrophils that directly secrete arachidonic acids, as well as inhibit secretion of histamine [17].

Results of this study were in line with the study of Umrah that leaf extracts of S. taccada (Gaertn.) Roxb. increased IL-10 levels as an anti-inflammatory effect [18].

Pathological analysis of breast tissues in the treated mice revealed that leaf extracts of $S$. taccada (Gaertn.) Roxb. could reduce damaged tissues, cellular infiltration, and subcutaneous edema due to induction of pathogens.

\section{Conclusion}

This study proved that leaf extracts of S. taccada (Gaertn) Roxb. had a significant function as an adjuvant for healing mastitis by reducing proinflammatory cytokine IL-1 $\beta$.

\section{Acknowledgment}

The authors are grateful to the authorities of Hasanuddin University Medical Research Centre for the facilities. 


\section{References}

1. Whiffin VS, van Paassen LA, Harkes MP. Microbial carbonate precipitation as a soil improvement technique. Geomicrobiol J. 2007;24(5):417-23. https://doi. org/10.1080/01490450701436505

2. Chandran A, Arunachalam G. Study of anti-inflammatory activity of Scaevola taccada Roxb. leaf extracts. Int J Phytopharmacol. 2013;4(4):263-5.

3. Sutar NG, Kulkarni A, Arangale KB. Literature review of Scavola taccada. World J Pharm Res. 2017;6(11):251-8.

4. Narayan KR. Handbook of Medicinal Plants. London: Sublime Publications; 2014.

5. Michele M. Isolation, Structural Elucidation, and Antibacterial Activity of the Chemical Constituents of Scaevola spinescens. Diss. School of Chemistry and Physics. Australia: University of Adelaide; 2009.

6. Rahmawati RS, Wati A, Herman H, Arsyad F. Test of antioxidant activity leave of Scaevola taccada (Geert.) Roxb using DPPH (1,1-diphenyl-2-picrylhidrazyl). Int Res J Pharm. 2014;5:159-62. https://doi.org/10.7897/2230-8407.050333

7. Jittra S, Thongsri $Y$, Yenjai C. A new furanocoumarin from the fruits of Scaevola taccada and antifungal activity against Pythium insidiosum. Nat Prod Res. 2017;31(4):453-9. https:// doi.org/10.1080/14786419.2016.1188100

PMid:27223164

8. Cecilia G, Dinarello CA, Mantovani A. The interleukin-1 family: Back to the future. Immunity. 2013;39(6):1003-18. https://doi. org/10.1016/j.immuni.2013.11.010

PMid:24332029

9. Borthwick LA. The IL-1 Cytokine Family and its Role in Inflammation and Fibrosis in the Lung. Semin Immunopathol 2016;38(4):517-34. https://doi.org/10.1007/s00281-016-0559-z PMid:27001429

10. Ke $R$, Torres $R$. Role of interleukin- $1 \beta$ during pain and inflammation. Brain Res Rev. 2009;60(1):57-64. https://doi. org/10.1016/j.brainresrev.2008.12.020

PMid:19166877

11. Wojdasiewicz P, Poniatowski AL, Szukiewicz D. The role of inflammatory and anti-inflammatory cytokines in the pathogenesis of osteoarthritis. Mediators Inflamm. 2014;2014:561459. https:// doi.org/10.1155/2014/561459

PMid:24876674

12. Chronis RN. Comparison of Cytokine Expression and Bacterial Growth during Periparturient and Mid Lactation Mastitis in a Mouse Model. Thesis, 2017. Available from: https://www.scholarsarchive. byu.edu/etd/6847. [Last acessed on 2020 Jan 20].

13. Lazzari M, de Oliveira MV, Moreti B, Guimaraes G, Krug F, Noleto $\mathrm{G}$, et al. Interleukin-1 $\beta$ production and severity of mastitis post-inoculation of Staphylococcus aureus in the mammary gland of bovines and bubalines. Cienc Rular Santa Maria. 2014;44(10):1816-22.

14. Kokate CK, Purohit AP, Gokhale SB. Pathway to Screen the Phytochemical Nature of Natural Drugs. Pharmacognosy. $39^{\text {th }}$ ed. India: Nirali Prakashan; 2007. p. 607-11.

15. Harborne AJ. Phytochemical Methods a Guide to Modern Techniques of Plant Analysis. Berlin, Germany: Springer Science and Business Media; 1998.

16. Zhang A, Yu Y, Liu F, Wang D, Zhou H, Zhang F. Effect of Staphylococcus aureus on the expressions of TLR2, IL-1 $\beta$, TNF$\alpha$, and NF-KB in B cap-37 cells. Vet Immunol Immunopathol. 2013;29(5):488-91.

PMid:23643268

17. Nijveldt RJ, van Nood E, van Hoorn DE, Boelens PG, van Norren K, van Leeuwen PA, et al. Flavonoids: A review of probable mechanisms of action and potential applications. Am J Clin Nutr. 2001;74(4):418-25.

PMid: 11566638

18. Sitti UA. The effectiveness of Scaevola tacada extract (Gaertn roxb) on the level of cytokine il-10 of strain Sprague Dawley (female laboratory rats) induced by the Staphylococcus aureus bacteria. Qanun Med Med J Fac Med Muhammadiyah Surabaya. 2018;2(2):1732. https://doi.org/10.30651/jqm.v2i2.1732 